\title{
PENDIDIKAN KEWIRAUSAHAAN DI LAPAS DENGAN PENDEKATAN MINAT USAHA
}

\author{
Sri Hapsari \& Dhova Shahroza \\ e-mail: hapsarisri@yahoo.com \\ Dosen Universitas Indraprasta PGRI
}

\begin{abstract}
Abstrak: Penelitian ini merupakan penelitian deskriptif yang bertujuan untuk mengetahui penerapan pendidikan kewirausahaan sehingga hasil penelitian ini dapat digunakan sebagai bahan kajian dalam pengembangan pendidikan kewirausahaan di Lapas anak wanita kelas II B Tangerang. Penelitian ini dilaksanakan pada bulan Oktober 2013 sampai dengan Februari 2014. Hasil penelitian ini menggambarkan kondisi para napi berdasarkan usia, delik kejahatan, agama, dan pendidikan. Di samping itu dipaparkan metode pendidikan kewirausahaan yang selama ini diterapkan di lapas anak wanita ini. Tahapan penelitian dimulai dengan: studi lapangan untuk identifikasi karakteristik napi yang meliputi pendidikan, agama, usia, delik kejahatan, dan minat usaha. Dari data yang diperoleh diketahui bahwa minat usaha napi di bidang dagang yakni sebesar $71 \%$. Dari mereka yang memilih usaha dagang, menceritakan bahwa sebelum mereka di lapas, mereka (keluarga) sudah memiliki usaha dagang serta pendidikan kewirausahan yang mereka dapat di lapas memberikan motivasi untuk membuka usaha nantinya.
\end{abstract}

Kata-kata kunci: kewirausahaan, pendidikan kewirausahaan, minat usaha

\section{ENTREPRENEURSHIP EDUCATION IN PRISON WITH BUSINESS INTEREST APPROACH}

\begin{abstract}
This descriptive research aimed to discover the implementation of entrepreneurship education that can be developed to be applied at Female Prison, IIB Class, Tangerang. The research conducted as from October 2013 through February 2014 describes the prisoners' characteristics by age, crime, religion, and education. Besides it also mentions the educational methods applied in the Female Prison. The research stages began with fileld study to obtain data related to education, religion, age, crime, and business interest. The data indicates their interest in commercial business is $71 \%$ with the background of business experience before they were taken into prison and the entrepreneurship education in the prison will motivate them to develop their previous commercial business or to start a business for those who have not done any commercial business.
\end{abstract}

Keywords: entrepreneurship, entrepreneurship training, commercial business intereset

\section{PENDAHULUAN}

Berdasarkan observasi yang dilakukan oleh penulis diperoleh keterangan bahwa karakteristik penghuni Lembaga Pemasyarakatan Anak Wanita Tangerang sangat heterogen baik dilihat dari faktor umur, pendidikan, hidup keagamaan, sosial ekonominya maupun tindak pidanya. Dengan keanekaragaman karakteristik ini, sebagai makhluk sosial, tiap individu dituntut agar mampu mengatasi segala permasalahan yang timbul sebagai akibat dari hasil interaksi dengan lingkungan sosial dan mampu menampilkan diri sesuai dengan aturan dan norma yang berlaku di masyarakat.

Setiap individu dituntut untuk menguasai keterampilan-keterampilan sosial dan kemampuan penyesuaian diri terhadap lingkungan sekitarnya. Keterampilan sosial dan kemampuan menyesuaikan diri semakin penting artinya ketika anak sudah menginjak usia remaja, karena pada masa remaja individu telah memasuki pergaulan yang lebih luas dan memiliki pengaruh teman-teman sebaya yang akan menentukan model perilakunya.

Kegagalan remaja dalam menguasai keterampilan-keterampilan sosial akan menyebabkan dia kesulitan dalam menyesuaikan diri dengan lingkungan sekitarnya sehingga dapat menyebabkan rasa rendah diri, dikucilkan dari pergaulan, dan cenderung berperilaku antisosial.

Masa remaja merupakan masa transisi dari masa anak menuju masa dewasa. Pada masa remaja, individu mengalami berbagai perubahan, baik secara fisik maupun psikis. Perubahan yang tampak jelas Jurnal IImiah VISI P2TK PAUD NI - Vol. 9, No.1, Juni 2014 
adalah perubahan fisik dimana tubuh berkembang pesat sehingga mencapai bentuk tubuh orang dewasa yang disertai dengan berkembangnya kapasitas reproduksi. Pada periode ini remaja mulai melepaskan diri secara emosional dari orang tua dalam menjalankan peran sosialnya yang baru sebagai orang dewasa.

Secara umum, masa remaja dibagi menjadi tiga bagian. Pertama, masa remaja awal 12 sampai dengan 15 tahun di mana pada masa ini individu mulai meninggalkan peran sebagai anak-anak dan berusaha mengembangkan diri sebagai individu yang unik dan tidak bergantung pada orang tua. Kedua, masa remaja pertengahan 15 sd.18 tahun yang ditandai dengan berkembangnya kemampuan berfikir yang baru. Teman sebaya masih memiliki peran penting, walaupun secara individu sudah lebih bisa mengarahkan diri sendiri (self-directed). Ketiga, masa remaja akhir 19 s.d. 22 tahun yang ditandai oleh persiapan akhir untuk memasuki peran-peran orang dewasa. Dalam periode ini individu remaja berusaha memantapkan tujuan vokasional dan mengembangkan sense of personal identity serta adanya keinginan yang kuat untuk menjadi matang dan diterima dalam kelompok teman sebaya dan orang dewasa.

Dewasa ini para remaja menghadapi tuntutan, harapan, serta resiko-resiko dan godaan-godaan yang lebih banyak dan kompleks. Resiko yang paling sering dialami oleh kalangan remaja antara lain seperti terjerumus kepada obat-obat terlarang, kenakalan remaja, kekerasan fisik, dan pencurian. Alhasil, tidak sedikit diantara mereka harus mendekam di bilik penjara untuk mempertanggungjawabkan perbuatan mereka. Selama di dalam lembaga permasyarakatan, tentunya bukan hal mudah bagi mereka bersosialisasi terutama menumbuhkan kembali rasa percaya diri mereka untuk bekal mereka nanti saat kembali pada masyarakat.

Bekal yang dimaksud dalam hal ini salah satunya adalah pendidikan kewirausahaan yang mereka dapatkan selama dalam lapas. Dengan demikian, Anak didik (andik) di dalam lapas ini memerlukan pembinaan dan pelatihan berwirausaha sesuai dengan minat, bakat, dan keterampilan masing-masing. Usaha pemberdayaan dalam bentuk pemberian pendidikan kewirausahaan ini diharapkan agar andik menjadi manusia mandiri. Rumusan masalah dalam penelitian ini adalah: (1) bagaimana pendidikan kewirausahaan di Lapas kelas II B Tangerang selama ini? dan (2) bagaimana antusias anak didik lapas dalam mengikuti pendidikan kewirausahaan dikaitkan dengan bakat dan minat mereka? Sedangkan tujuan dari penelitian ini adalah untuk mengetahui Pendidikan Kewirausahaan bagi anak didik Lapas agar menjadi manusia mandiri.
Berdasarkan uraian di atas maka kajian teori dalam penelitian ini yaitu sebagai berikut:

\section{A. Konsep Dasar Kewirausahaan}

Kewirausahaan pertama kali muncul pada abad 18 diawali dengan penemuan-penemuan baru seperti mesin uap, mesin pemintal, dan lain-lain. Tujuan utama mereka adalah pertumbuhan dan perluasan organisasi melalui inovasi dan kreativitas. Keuntungan dan kekayaan bukan tujuan utama.

Secara sederhana arti wirausahawan (entrepreneur) adalah orang yang berjiwa berani mengambil resiko untuk membuka usaha dalam berbagai kesempatan. Berjiwa berani mengambil resiko artinya bermental mandiri dan berani memulai usaha, tanpa diliputi rasa takut atau cemas sekalipun dalam kondisi tidak pasti. (Kasmir, 2007).

Dari pengertian di atas dapat ditarik kesimpulan bahwa kewirausahaan dipandang sebagai fungsi yang mencakup eksploitasi peluang-peluang yang muncul di pasar. Eksploitasi tersebut sebagian besar berhubungan dengan pengarahan dan atau kombinasi input yang produktif. Seorang wirausahawan selalu diharuskan menghadapi resiko atau peluang yang muncul, serta sering dikaitkan dengan tindakan yang kreatif dan innovatif. Wirausahawan adalah orang yang merubah nilai sumber daya, tenaga kerja, bahan dan faktor produksi lainnya menjadi lebih besar daripada sebelumnya dan juga orang yang melakukan perubahan, inovasi dan cara-cara baru.

Selain itu, seorang wirausahawan menjalankan peranan manajerial dalam kegiatannya, tetapi manajemen rutin pada operasi yang sedang berjalan tidak digolongkan sebagai kewirausahaan. Seorang individu mungkin menunjukkan fungsi kewirausahaan ketika membentuk sebuah organisasi, tetapi selanjutnya menjalankan fungsi manajerial tanpa menjalankan fungsi kewirausahaannya. Jadi kewirausahaan bisa bersifat sementara atau kondisional.

Kesimpulan lain dari kewirausahaan adalah proses penciptaan sesuatu yang berbeda nilainya dengan menggunakan usaha dan waktu yang diperlukan, memikul resiko finansial, psikologi dan sosial yang menyertainya, serta menerima balas jasa moneter dan kepuasan pribadi.

Istilah wirausaha muncul kemudian setelah dan sebagai padanan wiraswasta yang sejak awal sebagian orang masih kurang sreg dengan kata swasta. Persepsi tentang wirausaha sama dengan wiraswasta sebagai padanan entrepreneur. Perbedaannya adalah pada penekanan pada kemandirian (swasta) pada wiraswasta dan pada usaha (bisnis) pada wirausaha. Istilah wirausaha kini makin banyak digunakan orang 
terutama karena memang penekanan pada segi bisnisnya. Walaupun demikian mengingat tantangan yang dihadapi oleh generasi muda pada saat ini banyak pada bidang lapangan kerja, maka pendidikan wiraswasta mengarah untuk survival dan kemandirian seharusnya lebih ditonjolkan.

\section{B. Proses Kewirausahaan}

Secara umum tahap-tahap melakukan wirausaha yaitu: pertama, tahap memulai yaitu tahap dimana seseorang yang berniat untuk melakukan usaha mempersiapkan segala sesuatu yang diperlukan, diawali dengan melihat peluang usaha baru yang mungkin apakah membuka usaha baru, melakukan akuisisi, atau melakukan franchising. Juga memilih jenis usaha yang akan dilakukan apakah di bidang pertanian, industri / manufaktur / produksi atau jasa. Kedua, tahap melaksanakan usaha atau diringkas dengan tahap "jalan", tahap ini seorang wirausahawan mengelola berbagai aspek yang terkait dengan usahanya, mencakup aspek-aspek: pembiayaan, SDM, kepemilikan, organisasi, kepemimpinan yang meliputi bagaimana mengambil resiko dan mengambil keputusan, pemasaran, dan melakukan evaluasi.

Ketiga, mempertahankan usaha, tahap di mana wirausahawan berdasarkan hasil yang telah dicapai melakukan analisis perkembangan yang dicapai untuk ditindaklanjuti sesuai dengan kondisi yang dihadapi. Serta keempat, mengembangkan usaha, tahap di mana jika hasil yang diperoleh tergolong positif atau mengalami perkembangan atau dapat bertahan maka perluasan usaha menjadi salah satu pilihan yang mungkin diambil.

Secara internal, keinovasian dipengaruhi oleh faktor yang bersal dari individu, seperti locus of control, toleransi, nilai-nilai, pendidikan, pengalaman. Sedangkan faktor yang berasal dari lingkungan yang mempengaruhi diantaranya model peran, aktivitas, dan peluang. Oleh karena itu, inovasi berkembangan menajdi kewirausahaan melalui proses yang dipengrauhi lingkungan, organisasi dan keluarga (Suryana, 2001: 34).

Secara ringkas, model proses kewirausahaan mencakup tahap-tahap berikut (Alma, 2007): (1) proses inovasi, (2) proses pemicu, (3) proses pelaksanaan, (4) proses pertumbuhan.

Berdasarkan analisis pustaka terkait kewirausahaan, diketahui bahwa aspek-aspek yang perlu diperhatikan dalam melakukan wirausaha adalah: (a) mencari peluang usaha baru yaitu lama usaha yang dilakukan, dan jenis usaha yang pernah dilakukan, (b) pembiayaan yaitu pendanaan-jumlah dan sumber-sumber dana, (c) SDM yaitu tenaga kerja yang dipergunakan, (d) kepemilikan ialah peran-peran dalam pelaksanaan usaha, (e) organisasi yaitu pembagian kerja diantara tenaga kerja yang dimiliki, (f) kepemimpinan yaitu kejujuran, agama, tujuan jangka panjang, proses manajerial (POAC), (g) Pemasaran yaitu lokasi dan tempat usaha

\section{Faktor-faktor Motivasi Berwirausaha}

Ciri-ciri wirausaha yang berhasil (Kasmir, 2007):

pertama, memiliki visi dan tujuan yang jelas. Hal ini berfungsi untuk menebak ke mana langkah dan arah yang dituju sehingga dapat diketahui langkah yang harus dilakukan oleh pengusaha tersebut. Kedua, Inisiatif dan selalu proaktif. Ini merupakan ciri mendasar di mana pengusaha tidak hanya menunggu sesuatu terjadi, tetapi terlebih dahulu memulai dan mencari peluang sebagai pelopor dalam berbagai kegiatan.

Ketiga, berorientasi pada prestasi. Pengusaha yang sukses selalu mengejar prestasi yang lebih baik daripada prestasi sebelumnya. Mutu produk, pelayanan yang diberikan, serta kepuasan pelanggan menjadi perhatian utama. Setiap waktu segala aktivitas usaha yang dijalankan selalu dievaluasi dan harus lebih baik dibanding sebelumnya. Keempat, berani mengambil risiko. Hal ini merupakan sifat yang harus dimiliki seorang pengusaha kapanpun dan dimanapun, baik dalam bentuk uang maupun waktu.

Kelima, yaitu kerja keras. Jam kerja pengusaha tidak terbatas pada waktu, di mana ada peluang di situ dia datang. Kadang-kadang seorang pengusaha sulit untuk mengatur waktu kerjanya. Benaknya selalu memikirkan kemajuan usahanya. Ide-ide baru selalu mendorongnya untuk bekerja kerjas merealisasikannya. Tidak ada kata sulit dan tidak ada masalah yang tidak dapat diselesaikan. Keenam, bertanggungjawab terhadap segala aktifitas yang dijalankannya, baik sekarang maupun yang akan datang. Tanggungjawab seorang pengusaha tidak hanya pada segi material, tetapi juga moral kepada berbagai pihak.

Ketujuh, komitmen pada berbagai pihak merupakan ciri yang harus dipegang teguh dan harus ditepati. Komitmen untuk melakukan sesuatu memang merupakan kewajiban untuk segera ditepati dana direalisasikan. Serta kedelapan, mengembangkan dan memelihara hubungan baik dengan berbagai pihak, baik yang berhubungan langsung dengan usaha yang dijalankan maupun tidak. Hubungan baik yang perlu dlijalankan, antara lain kepada para pelanggan, pemerintah, pemasok, serta masyarakat luas.

Dari analisis pengalaman di lapangan, ciri-ciri wirausaha yang pokok untuk dapat berhasil dapat dirangkum dalam tiga sikap, yaitu: (a) jujur, dalam arti berani untuk mengemukakan kondisi sebenarnya dari 
usaha yang dijalankan, dan mau melaksanakan kegiatan usahanya sesuai dengan kemampuannya. Hal ini diperlukan karena dengan sikap tersebut cenderung akan membuat pembeli mempunyai kepercayaan yang tinggi kepada pengusaha sehingga mau dengan rela untuk menjadi pelanggan dalam jangka waktu panjang ke depan; (b) mempunyai tujuan jangka panjang, dalam arti mempunyai gambaran yang jelas mengenai perkembangan akhir dari usaha yang dilaksanakan. Hal ini untuk dapat memberikan motivasi yang besar kepada pelaku wirausaha untuk dapat melakukan kerja walaupun pada saat yang bersamaan hasil yang diharapkan masih juga belum dapat diperoleh; (c) selalu taat berdoa, yang merupakan penyerahan diri kepada Tuhan untuk meminta apa yang diinginkan dan menerima apapun hasil yang diperoleh. Dalam bahasa lain, dapat dikemukakan bahwa "manusia yang berusaha, tetapi Tuhan-lah yang menentukan!" dengan demikian berdoa merupakan salah satu terapi bagi pemeliharaan usaha untuk mencapai cita-cita.

Delapan anak tangga menuju puncak karir berwirausaha (Alma, 2007), terdiri atas: (1) mau kerja keras (capacity for hard work), (2) bekerjasama dengan orang lain (getting things done with and through people), (3) penampilan yang baik (good appearance), (4) yakin (self confidence), (5) pandai membuat keputusan (making sound decision), (6) mau menambah ilmu pengetahuan (college education), (7) ambisi untuk maju (ambition drive), (8) pandai berkomunikasi (ability to communicate).

\section{Kajian Minat Wirausaha}

Minat berwirausahan sangat dipengaruhi oleh motivasi dan dalam bidang Psikologi, teori motivasi yang paling mendekati adalah motivasi berprestasi dari David McLelland (dalam Wade \& Tavris, 2007;175), McLelland menyatakan bahwa "beberapa orang memiliki kebutuhan berprestasi yang memotivasi mereka, sebagaimana rasa lapar memotivasi orang untuk makan, dan kekuatan motif berprestasi ditunjukkan dalam fantasi". Dalam penelitian yang sudah dilakukan, para partisipan (penghuni lapas) dimintai pendapatnya mengenai masa depan mereka, inilah yang dimaksud fantasi dalam teori McLelland, mereka diminta untuk membayangkan atau menggambarkan masa depan mereka dalam bidang wirausaha, sedangkan bidang usaha yang mereka pilih adalah motivasi berprestasi yang mereka miliki untuk menggapai hasil (motivasi perprestasi).

Teori lain yang sesuai dan seiring dengan teori McLelland adalah teori dari Albert Bandura mengenai dua kategori self yaitu self-fulfilling prophecy dan self-efficacy (dalam Wade \& Tavris, 2007;180). Selffulfilling prophecy adalah suatu harapan yang menjadi kenyataan karena orang yang memiliki harapan tersebut cenderung tetap bertahan pada harapan tersebut, dan melakukan tindakan-tindakan yang dapat merealisasikan harapan tersebut. Sedangkan self-efficacy merupakan keyakinan seseorang bahwa dirinya mampu meraih hasil yang diinginkan, seperti penguasaan suatu keterampilan baru atau mencapai suatu tujuan.

Kedua teori Psikologi di atas sangat berkaitan erat jika dihubungkan dengan penelitian mengenai minat kewirausahaan. Dalam berwirausaha, bukan hanya diperlukan mimpi saja untuk mencapai keberhasilan namun niat, motivasi atau dorongan yang kuat untuk berprestasi serta keterampilan atau pelatihanpelatihan terkait juga sangat diperlukan agar berhasil dan sukses dibidang wirausaha, mengingat jaman sekarang bidang wirausaha sudah sangat beragam dan menjamur. Jika usahawan tidak mampu "melihat" pangsa pasar atau salah memilih bidang usaha, sudah dapat dikatakan kegagalan ada di depan mata karena mungkin usaha yang dipilih "biasa-biasa" saja menurut masyarakat.

Berdasarkan definisi di atas, maka yang dimaksud dengan minat wirausaha adalah keinginan, ketertarikan serta kesediaan untuk bekerja keras atau berkemauan keras dengan adanya pemusatan perhatian untuk berusaha memenuhi kebutuhan hidupnya tanpa merasa takut akan resiko yang akan dihadapi, senantiasa belajar dari kegagalan yang dialami, serta mengembangkan usaha yang diciptakannya. Minat wirausaha tersebut tidak hanya keinginan dari dalam diri saja tetapi harus melihat ke depan dalam potensi mendirikan usaha.

\section{METODE PENELITIAN}

Penelitian ini menggunakan metode kualitatif yang dilaksanakan pada program pendidikan kewirausahaan di Lapas kelas II B Tangerang. Strategi penelitian kualitatif yang digunakan adalah studi kasus yakni strategi penelitian dimana di dalamnya peneliti menyelidiki secara cermat suatu program, peristiwa, aktivitas, proses, atau sekelompok individu (Creswell, 2010). Kasus-kasus dibatasi oleh waktu dan aktivitas, dan peneliti mengumpulkan informasi secara lengkap dengan menggunakan berbagai prosedur pengumpulan data berdasarkan waktu yang telah ditentukan.

Teknik pengumpulan data dengan kepustakaan, 
observasi, dan wawancara. Program yang diamati oleh peneliti adalah program pendidikan kewirausahaan berupa pelatihan keterampilan. Dalam penelitian kualitatif ini, tidak terlalu dibutuhkan random sampling atau pemilihan secara acak terhadap para partisipan dan lokasi penelitian, yang biasanya dijumpai dalam penelitian kuantitatif. Sedangkan untuk mengetahui minat penghuni lapas terhadap bidang usaha, pengambilan sampel ini hanya sebagai data pendukung dari data kualitatif yang tersedia. Pembahasan mengenai para partisipan dan lokasi penelitian dapat mencakup empat aspek (Miles dan Huberman dalam Creswell) yaitu: setting, aktor, peristiwa, dan proses (Creswell, 2010:267). Dalam penelitian ini, setting penelitian adalah di lapas kelas II B Tangerang, dan aktor dalam penelitian ini yang dimaksud adalah orang-orang yang diobservasi atau diwawancarai yakni meliputi nara pidana wanita, serta petugas lapas di bagian pendidikan keterampilan. Sedangkan peristiwa, bahwasanya penulis mendapatkan respons yang positif dari para nara sumber, penulis mendapatkan kemudahan dalam memperoleh data-data yang diperlukan. Mengenai proses yang terjadi mencakup peristiwa yang dirasakan oleh aktor. Penulis mendapatkan informasi dari bagian pendidikan kewirausahaan di lapas bahwa bukan hal mudah dalam memotivasi warga belajar (napi) untuk aktif dalam pendidikan kewirausahaan ini. Hal ini dikarenakan emosi mereka yang bisa dikatakan naik-turun, kadang diantara mereka merindukan ke- luarganya sehingga yang ia lakukan hanya bersedih sehingga tidak mau melakukan aktivitas. Disamping itu, pihak kependidikan tidak mau memaksakan warga belajar untuk aktif berpartisipasi karena dikhawatirkan akan dituduh eksploitasi anak.

Skenario penelitian dimulai dari mendiagnosis karakteristik anak didik, program pendidikan yang diberikan. Skenario riset dapat digambarkan sebagai berikut:

Tabel 1. Skenario Riset

\begin{tabular}{|l|l|}
\hline \multicolumn{1}{|c|}{ Proses } & \multicolumn{1}{c|}{ Output } \\
\hline $\begin{array}{l}\text { 1. Pemetaan Karakteristik } \\
\text { Andik Lapas }\end{array}$ & $\begin{array}{l}\text { 1. Karakteristik berdasarkan } \\
\text { usia, pendidikan, minat } \\
\text { wirausaha, katerogori andik, } \\
\text { bentuk kejahatan, dan agama. }\end{array}$ \\
\hline $\begin{array}{l}\text { 2. observasi pendidikan kewi- } \\
\text { rausahaan }\end{array}$ & $\begin{array}{l}\text { 2. Analisis pendidikan kewi- } \\
\text { rausahaan yang selama ini } \\
\text { dilaksanakan }\end{array}$ \\
\hline $\begin{array}{l}\text { 3. identifikasi minat wi- } \\
\text { rausaha }\end{array}$ & 3. Gambaran minat wirausaha \\
\hline
\end{tabular}

Adapun jadwal kegiatan dalam penelitian ini dilaksanakan pada bulan Oktober 2013-Februari 2014. Diawali dengan penyusunan proposal pada minggu ke-3 Oktober sampai dengan minggu ke-2 November 2013. Selanjutnya penulis mengurus perizinan dan penyusunan instrumen pada bulan Desember. Dan penelitian dimulai pada bulan Januari 2014 sampai dengan Februari minggu ke-2. Sedangkan pelaporan pada minggu ke-3 dan ke-4 Februari 2014.

\section{HASIL DAN PEMBAHASAN}

\section{A. Kewirausahaan yang Diberikan}

Pelatihan keterampilan kewirausahaan diberikan setian hari Senin sampai Kamis pukul 10.00-12.00. Keterampilan tersebut diantaranya menjahit, meronce (mute), dan menyulam. Anak didik tahun lalu (2013) diberikan pelatihan membatik dan menjahit. Dana penyelenggaraan pelatihan tersebut diperoleh dari Dipa Kemenkumham, namun tahun ini (2014) tidak mendapatkan Dipa.

Produk hasil keterampilan ini dipamerkan di galeri lapas dan diperjualbelikan. Kadang pihak lapas juga memasarkan produk keluar bila ada pameran. Selama ini pendidikan wirausaha diberikan bila ada kemauan anak didik atau tahanan dan saat tidak ada kegiatan lain seperti kunjungan sehingga pendidikan diberkan tanpa paksaan.

B. Penghuni Lembaga Pemasyarakatan Anak Wanita Tangerang

Menurut UU No. 12 Tahun 1995 pasal I ayat $8 a, 8 b, 8 c$ anak didik (sebutan untuk penghuni Lem- baga Pemasyarakatan Anak Wanita Tangerang) dapat dibedakan kepada: (a) Anak Negara yaitu anak yang berdasarkan putusan pengadilan diserahkan pada negara untuk dididik dan ditempatkan di Lembaga Pemasyarakatan Anak paling lama sampai berumur 18 (delapan belas) tahun, (b) anak Sipil yaitu anak yang atas permintaan orang tua atau walinya memperoleh penetapan pengadilan untuk dididik di Lembaga Pemasyarakatan Anak paling lama sampai berumur 18 (delapan belas) tahun, dan (c) anak pidana yaitu anak yang berdasarkan putusan pengadilan menjalani pidana di Lembaga Pemasyarakatan Anak, dan umur mereka belum mencapai 22 tahun.

Saat ini (data 2014) penghuni Lapas anak wanita dihuni oleh anak didik sebanyak 13 orang dan tahanan dewasa (titipan) sebanyak 66 orang. 
Tabel 2. Pendidikan Anak Pidana dan Tahanan Dewasa

\begin{tabular}{|l|c|c|c|c|c|}
\hline $\begin{array}{c}\text { Tingkat } \\
\text { Pendi- } \\
\text { dikan }\end{array}$ & $\begin{array}{c}\text { Anak } \\
\text { Ne- } \\
\text { gara }\end{array}$ & $\begin{array}{c}\text { Anak } \\
\text { Sipil }\end{array}$ & $\begin{array}{c}\text { Anak } \\
\text { Pidana }\end{array}$ & $\begin{array}{c}\text { Ta- } \\
\text { hanan } \\
\text { Anak }\end{array}$ & Jml \\
\hline $\begin{array}{l}\text { Buta } \\
\text { Huruf }\end{array}$ & - & - & - & - & - \\
\hline SD & - & - & 4 & - & 4 \\
\hline SMP & - & - & 6 & - & 6 \\
\hline SMA & - & - & 3 & - & 3 \\
\hline Jumlah & - & - & 13 & - & 13 \\
\hline
\end{tabular}

Berdasarkan tabel di atas diketahui bahwa untuk kategori anak pidana, tingkat pendidikan yang paling banyak dimiliki adalah tingkat SMP yakni sebanyak 6 orang anak pidana. Sedangkan pendidikan SMA paling sedikit dimiliki oleh anak pidana yakni sebanyak 3 orang dan pendidikan SD sebanyak 4 orang anak pidana.

Tabel 3. Tingkat Pendidikan Narapidana

\begin{tabular}{|c|c|}
\hline Tingkat Pendidikan & Narapidana \\
\hline Buta Huruf & 3 \\
\hline SD & 11 \\
\hline SMP & 20 \\
\hline SMA/SMK & 31 \\
\hline S1 & 1 \\
\hline
\end{tabular}

Berbeda dengan tahanan dewasa/napi, pendidikan SMA/K paling banyak dimiliki yakni sebanyak 31 napi dewasa, disusul SMP sebanyak 20 orang, SD sebanyak 11 orang, buta huruf 3 orang, serta adapula napi yang sudah Sarjana S1 yakni 1 orang.

Tabel 4. Usia Penghuni Lapas anak wanita, tahanan dewasa dan narapidana dewasa

\begin{tabular}{|c|c|c|c|c|}
\hline Usia & $\begin{array}{c}\text { Anak } \\
\text { didik }\end{array}$ & $\begin{array}{c}\text { Tahanan } \\
\text { dewasa }\end{array}$ & Narapidana & Jml \\
\hline 13 tahun & - & - & - & - \\
\hline 15 tahun & - & - & - & - \\
\hline 16 tahun & - & - & - & - \\
\hline 17 tahun & 4 & 2 & - & 6 \\
\hline 18 tahun & 2 & 1 & - & 3 \\
\hline 19 tahun & 2 & 1 & - & 3 \\
\hline 20 tahun & - & - & 4 & 4 \\
\hline 21 tahun & - & - & 2 & 2 \\
\hline $\begin{array}{c}>21 \\
\text { tahun }\end{array}$ & 1 & - & 60 & 61 \\
\hline Jumlah & - & - & - & 79 \\
\hline
\end{tabular}

Berdasarkan tabel di atas, penghuni paling banyak justru dari napi dewasa yakni 60 orang. Pada lapas anak wanita ini, mereka mendapat titipan napi dewasa karena di lapas wanita mengalami overload sehingga mereka dititipkan di lapas anak wanita ini. Walaupun demikian, hunian mereka dipisahkan dari anak wanita.

Tabel 5. Agama Penghuni Lembaga

Pemasyarakatan Anak Wanita Tangerang

\begin{tabular}{|c|c|c|c|c|}
\hline Agama & $\begin{array}{c}\text { Anak } \\
\text { didik }\end{array}$ & $\begin{array}{c}\text { Tahanan } \\
\text { Dewasa }\end{array}$ & $\begin{array}{c}\text { Narapi- } \\
\text { dana }\end{array}$ & Jumlah \\
\hline Islam & 7 & 4 & 61 & 72 \\
\hline Kristen & 2 & - & 1 & 3 \\
\hline Khatolik & - & - & 1 & 1 \\
\hline Budha & - & - & 3 & 3 \\
\hline
\end{tabular}

Agama penghuni lapas paling banyak yakni agama Islam sebanyak 72 orang, kemudian Kristen 3 orang, Budha 3 orang, dan Khatolik 1 orang.

Tabel 6. Bentuk Kejahatan Penghuni Lembaga Pemasyarakatan Anak Wanita Tangerang

\begin{tabular}{|c|l|c|c|c|c|}
\hline No. & $\begin{array}{c}\text { Bentuk } \\
\text { Keja- } \\
\text { hatan }\end{array}$ & $\begin{array}{c}\text { Anak } \\
\text { didik }\end{array}$ & $\begin{array}{c}\text { Ta- } \\
\text { hanan } \\
\text { Dewasa }\end{array}$ & $\begin{array}{c}\text { Narapi- } \\
\text { dana }\end{array}$ & Jml \\
\hline 1. & Narkoba & 5 & 2 & 61 & 68 \\
\hline 2. & Perampokan & - & - & - & - \\
\hline 3. & Pencurian & - & - & - & - \\
\hline 4. & $\begin{array}{l}\text { Pem- } \\
\text { bunuhan }\end{array}$ & - & - & - & - \\
\hline 5. & $\begin{array}{l}\text { Penggela- } \\
\text { pan }\end{array}$ & - & - & $1^{*}$ & 1 \\
\hline 6. & $\begin{array}{l}\text { Penganiay- } \\
\text { aan }\end{array}$ & - & - & & \\
\hline 7. & Penipuan & - & - & $2^{*}$ & 2 \\
\hline 8. & $\begin{array}{l}\text { Pelanggaran } \\
\text { Tata Tertib }\end{array}$ & - & - & & \\
\hline 9. & Kenakalan & - & - & & \\
\hline 10. & Penadahan & - & - & & \\
\hline 11. & $\begin{array}{l}\text { Penelanta- } \\
\text { ran Anak }\end{array}$ & - & - & $1^{*}$ & 1 \\
\hline 12. & Aborsi & - & - & & \\
\hline 13. & Eksploitasi & - & - & $2^{*}$ & 2 \\
\hline
\end{tabular}

*perlu konfirmasi kembali

Delik kejahatan mayoritas yakni narkoba baik pada anak maupun dewasa.

C. Proses Pelaksanaan Pendidikan Kewirausahaan

Berdasarkan data yang diperoleh per Januari 2014, bimbingan yang dilaksanakan sebagai berikut: (1) memasak, peralatan yang digunakan yakni kompor, penggorengan, dan panci. Sedangkan bahan yang dipergunakan meliputi mie, tepung terigu, telur, cabe, 
dll. Pada kegiatan memasak ini diikuti oleh 2 orang; (2) menjahit, peralatan yang digunakan yakni mesin jahit, jarum, gunting. Sedangkan bahan yang dipergunakan meliputi bahan blaco, benang sulam, dll. Pada kegiatan menjahit ini diikuti oleh 2 orang; (3) berkebun, peralatan yang digunakan yakni cangkul, garpu, arit. Sedangkan bahan yang dipergunakan bibit sayuran, pupuk, dll. Pada kegiatan berkebun ini diikuti oleh 8 orang; (4) menyulam, peralatan yang digunakan yakni jarum, pemidangan, gunting. Sedangkan bahan yang dipergunakan meliputi kain, benang. Pada kegiatan ini diikuti oleh 4 orang; (5) merawat taman, peralatan yang digunakan meliputi cangkul, ember, selang, arit. Sedangkan bahan yang dipergunakan meliputi pohon hias, pupuk, obat. Pada kegiatan ini diikuti oleh 1 orang; (6) merawat pondokan tanaman hias, peralatan yang digunakan meliputi selang, tang potong, ember, arit. Sedangkan bahan yang dipergunakan meliputi pohon hias, pupuk, obat. Pada kegiatan ini diikuti oleh 1 orang; (7) budidaya anggrek, peralatan yang digunakan meliputi selang, tang potong, ember, arit. Sedangkan bahan yang dipergunakan meliputi pupuk, anggrek, obat. Pada kegiatan ini diikuti oleh 1 orang, (8) budidaya mujair, peralatan yang digunakan ember dan selang. Sedangkan bahan yang dipergunakan adalah lele, air, dan pakan. Pada kegiatan ini diikuti oleh 1 orang; (9) membatik, peralatan yang digunakan meliputi kompor, canting, penggorengan. Sedangkan bahan yang dipergunakan meliputi kain, lilin, dan pewarna. Pada kegiatan ini diikuti oleh 3 orang; (10) membordir, peralatan yang digunakan meliputi jarum, gunting, pemidangan. Sedangkan bahan yang dipergunakan meliputi kain dan benang. Pada kegiatan ini diikuti oleh 1 orang; (11)membuat kKeset, peralatan yang digunakan meliputi alat pembuat keset, gunting, pinset. Sedangkan bahan yang dipergunakan adalah perca. Pada kegiatan ini diikuti oleh 2 orang; (12) Kerajinan Motte, peralatan yang digunakan meliputi tang dan gunting. Sedangkan bahan yang dipergunakan motte, kawat, dll. Pada kegiatan ini diikuti oleh 2 orang; (13) Kerajinan Tutup Gelas, peralatan yang digunakan yakni gunting dan tembakan lem. Sedangkan bahan yang dipergunakan adalah tutup gelas, kain lamer, dan lem. Pada kegiatan ini diikuti oleh 3 orang; dan (14) Lukis Kerudung.

Peralatan yang digunakan adalah pemidangan dan kuas. Sedangkan bahan yang dipergunakan adalah cat dan air. Pada kegiatan ini diikuti oleh 3 orang. Berdasarkan gambaran bimbingan/pelatihan di atas, kegiatan yang paling banyak diminati yakni berkebun. Beberapa napi yang kami wawancarai, bahwa mereka memilih berkebun karena dinilai lebih mudah dan dapat dilaksanakan. Selain itu, diketahui bahwa mayoritas napi yang berkebun berusia di atas 40 tahun. Bisa dikatakan, mata mereka tidak lagi awas bila harus memasukkan jarum bila harus mengikuti kegiatan menjahit. Seperti halnya di Jepang, bahwasanya keterampilan yang cocok bagi usia yang tidak lagi muda adalah bercocok tanam. Dengan bercocok tanam, dapat memberikan ketenangan dan menghilangkan stress.

Jumlah andik (anak didik)/tahanan yang mengikuti pendidikan ini pun dapat dikatakan jauh dari jumlah penghuni lapas. Pihak lapas berdalih, mereka tidak memaksa andik untuk mengikuti pendidikan ini karena lapas ini dikhususkan bagi anak wanita jadi ada kekhawatiran bila dipaksa akan dinilai 'mengeksplotasi' anak. Selain itu, kondisi para tahanan yang berbeda dengan orang bebas diluar sana secara psikologis. Mereka rentan sekali terhadap stress yang kadang kala hal ini disebabkan oleh hal yang "sepele" tapi bagi mereka yang terisolasi akan menjadi luar biasa. Misalnya saja, saat mereka menunggu telp dari keluarga ternyata pihak keluarga tidak menelpon, ada juga yang sudah lama tidak dijenguk sehingga rasa rindu membuat mereka stress sehingga berakibat tidak mau melaksanakan aktivitas di lapas.

D. Gambaran Minat Wirausaha Anak Didik/tahanan Lapas kelas II B Tangerang

Penulis mendapatkan data gambaran minat wirausaha responden teknik yang digunakan yakni nonprobability sampel, memang kurang menarik karena sampel yang diambil berdasarkan kemudahan (convinience) daan ketersediaannya (Barbie dalam Creswell, 2010). Penulis memandang bahwa bukan hal mudah untuk mewawancarai para napi disamping itu para napi sedang ada aktivitas sehingga penulis mengambil yang bersedia saja. Pertanyaan mengenai usaha apa yang mereka minati atau akan digeluti usai keluar dari lapas akan dijelaskan pada tabel 7 .

Tabel 7. Minat Usaha Penghuni Lapas

\begin{tabular}{|c|l|c|c|c|c|c|}
\hline No. & \multicolumn{1}{|c|}{ Nama } & $\begin{array}{c}\text { Minat } \\
\text { Usaha }\end{array}$ & Dagang & Agraris & Jasa & Properti \\
\hline 1. & Mulyami & - & - & - & $\sqrt{ }$ & \\
\hline 2. & Rosidah & $\sqrt{ }$ & - & - & - & - \\
\hline
\end{tabular}




\begin{tabular}{|c|c|c|c|c|c|c|}
\hline No. & Nama & $\begin{array}{l}\text { Minat } \\
\text { Usaha }\end{array}$ & Dagang & Agraris & Jasa & Properti \\
\hline 3. & Fitriyani & $\sqrt{ }$ & - & - & - & - \\
\hline 4. & Ayu & - & - & $\sqrt{ }$ & - & - \\
\hline 5. & Reza & - & - & $\sqrt{ }$ & - & - \\
\hline 6. & Nurma & $\sqrt{ }$ & & & - & - \\
\hline 7. & Silvia & - & - & $\sqrt{ }$ & - & - \\
\hline 8. & Susilawati & - & - & $\sqrt{ }$ & - & - \\
\hline 9. & Sukmawati & $\sqrt{ }$ & - & - & - & - \\
\hline 10. & Fransiska & $\sqrt{ }$ & - & - & - & - \\
\hline 11. & Windiarti & $\sqrt{ }$ & - & - & - & - \\
\hline 12 & Nuraeni & $\sqrt{ }$ & - & - & - & - \\
\hline 13. & Nendah & $\sqrt{ }$ & - & - & - & - \\
\hline 14. & Solekhawati & $\sqrt{ }$ & - & - & - & - \\
\hline 15. & Cici & $\sqrt{ }$ & - & - & - & - \\
\hline 16. & Linda & - & - & $\sqrt{ }$ & - & - \\
\hline 17. & Rani & $\sqrt{ }$ & - & - & - & - \\
\hline 18. & Nengsih & $\sqrt{ }$ & - & - & - & - \\
\hline 19. & Ade & $\sqrt{ }$ & - & - & - & - \\
\hline 20. & Tjiam & $\sqrt{ }$ & - & - & - & - \\
\hline 21. & Laddy & $\sqrt{ }$ & & & - & - \\
\hline 22. & Eka & - & - & $\sqrt{ }$ & - & - \\
\hline 23. & Fia & $\sqrt{ }$ & - & - & - & - \\
\hline 24 & Astinah & $\sqrt{ }$ & - & - & - & - \\
\hline
\end{tabular}

Dari hasil perhitungan didapati bahwa minat untuk berwirausaha dibidang dagang sebesar $71 \%$, bidang jasa $25 \%$, bidang properti $4 \%$ dan bidang agraris $0 \%$. Berdasarkan gambaran bimbingan/pelatihan yang disajikan di atas, kegiatan yang paling banyak diminati yakni berkebun. Beberapa napi yang kami wawancarai, bahwa mereka memilih berkebun karena dinilai lebih mudah dan dapat dilaksanakan. Selain itu, diketahui bahwa mayoritas napi yang berkebun berusia di atas 40 tahun. Bisa dikatakan, mata mereka tidak lagi awas bila harus memasukkan jarum bila harus mengikuti kegiatan menjahit. Seperti halnya di Jepang, bahwasanya keterampilan yang cocok bagi usia yang tidak lagi muda adalah bercocok tanam. Dengan bercocok tanam, dapat memberikan ketenangan dan menghilangkan stress.

Jumlah andik (anak didik)/tahanan yang mengikuti pendidikan ini pun dapat dikatakan jauh dari jumlah penghuni lapas. Pihak lapas berdalih, mereka tidak memaksa andik untuk mengikuti pendidikan ini karena lapas ini dikhususkan bagi anak wanita jadi ada kekhawatiran bila dipaksa akan dinilai "mengeksplotasi' anak. Selain itu, kondisi para tahanan yang berbeda dengan orang bebas diluar sana secara psikologis.
Mereka rentan sekali terhadap stres yang kadang kala hal ini disebabkan oleh hal yang "sepele" tapi bagi mereka yang terisolasi akan menjadi luar biasa. Misalnya saja, saat mereka menunggu telpon dari keluarga ternyata pihak keluarga tidak menelpon, ada juga yang sudah lama tidak dijenguk sehingga rasa rindu membuat mereka stres sehingga berakibat tidak mau melaksanakan aktivitas di lapas.

Sedangkan untuk minat usaha, paling banyak adalah dibidang dagang. Ini kemungkinan besar dikarenakan sebelum mereka ada di lapas, mereka sudah bergelut dibidang yang sama, dan mereka juga selama mendapatkan pelatihan kewirausahaan sudah diberikan gambaran mengenai keuntungan besar yang bisa mereka peroleh di kemudian hari dalam berwirausaha jika memiliki keterampilan khusus, yaitu melalui salah satu usahanya adalah pelatihan keterampilan yang didapat selama berada di lapas.

Untuk hasil dibidang lain seperti jasa, properti dan agraris yang jumlahnya jauh lebih sedikit, ini besar kemungkinan dikarenakan orientasi mereka berwirausaha melalui bidang dagang adalah lebih cepat mendapatkan pemasukan, sedangkan bidang lainnya memerlukan tenaga dan waktu yang lebih. Faktor usia 
yang masih muda juga mempengaruhi daya juang mereka untuk bertahan hidup sangat kecil, karena hal ini yang menyebabkan mereka menginginkan segala susatunya yang cepat dan nyata.

\section{PENUTUP}

\section{Kesimpulan}

Berdasarkan hasil penelitian seperti disebut di atas, maka dapat disimpulkan bahwa (1) Pendidikan kewirausahaan yang diberikan oleh pihak lapas yakni berupa pemberian pelatihan keterampilan. Ada 14 program pelatihan pendidikan yakni memasak, menjahit, berkebun, menyulam, merawat taman, merawat pondokan tanaman hias, budidaya anggrek, budidaya mujair, membatik, membordir, membuat keset, kerajinan motte, kerajinan tutup gelas, dan lukis kerudung, dan (2) terdapat tiga usaha yang paling diminati, antara lain: Usaha Dagang, sebesar $71 \%$ meliputi bidang menjahit, memasak, keterampilan (handmade), dan sales. Usaha Jasa, sebesar $25 \%$ meliputi bidang menjahit, membatik. Usaha Properti, sebesar 4\%.

Saran

Adapun saran dalam penelitian ini, diharapkan penelitian ini dapat dilanjutkan menjadi model pengembangan pendidikan kewirausahaan di lapas sehingga dapat digeneralisasikan di instansi serupa.

\section{DAFTAR PUSTAKA}

Alma, Buchari. (2007). Kewirausahaan, edisi revisi. Bandung: Penerbit Alfabeta.

Kasmir. (2007). Kewirausahaan. Jakarta: PT RajaGrafindo Perkasa.

Carole Wade \& Carol Tavris. (2007). Psikologi. Jilid 2. Edisi Kesembilan. Jakarta: Penerbit Erlangga.
Creswell, John W. (2010). Research design: Pendekatan kualitatif, kuantitatif, dan mixed. Yogyakarta: Pustaka Pelajar.

Suryana. (2001). Kewirausahaan. Jakarta: Penerbit Salemba Empat. 